\title{
REPORT ON A VISIT TO THE RUSSIAN STATE UNIVERSITY OF PHYSICAL EDUCATION, SPORT, YOUTH AND TOURISM
}

\author{
Moscow, Russian Federation, $14^{\text {th }}-18^{\text {th }}$ May 2019
}

Within the framework of the bilateral cooperation between Slovenia and Russian Federation, a few colleagues from the Institute for Kinesiology Research of SRC Koper paid a visit to the Russian State University of Physical Education, Sport, Youth and Tourism was held between $14^{\text {th }}$ and $18^{\text {th }}$ May 2019. Our kind hosts were Elena Komova, $\mathrm{PhD}$, and prof. Sergei Levuskhin, $\mathrm{PhD}$, who showed us the university and the laboratory of the Research Institute for Sports and Sports Medicine, where we got acquainted with the research associates, equipment, different measurements and researches as well as how the institute functions. At the same time, our research work and scientific capacities were presented to our Russian partners in bilateral cooperation.

On $16^{\text {th }}$ May 2019, we were invited to lecture at introductory session at XIII. "Contemporary University Sport Science", a conference dedicated to graduate students and their international experiences. Prof. Boštjan Šimunič, $\mathrm{PhD}$, participated with the lecture "The use of methods of tensiomyography in the study of atrophies" while Saša Pišot, PhD with the lecture titled: "Basic motor patterns and physical (embodied) capital of the child." The following day, on $17^{\text {th }}$ May 2019, we also participated in a roundtable discussion held at the conference entitled: World Sports Development Systems and Elite Athletes' Access to Education. The topic of the round table was about the current good practices and shortcomings of the systems in Russia, Egypt and Slovenia, where Prof. Rado Pišot, $\mathrm{PhD}$, presented the results of the project "Double Career (2D4C)", while Prof. Smolianov presented his research of elite sports development systems around the world, currently in the US, UK, Senegal and Qatar. In the afternoon we had a meeting with Prof. Valentin Sonkin, $\mathrm{PhD}$, who explained us their work in detail. We all recognised several common interests in further research, above all in the fields of muscle physiology.

The first visit can be considered a success since we have had an important insight into the work of our partner institutions and have made a new acquaintance for a successful cooperation in research on the field of motor status components of children and adolescents with an emphasis on their assessment and measurement. The next step we are going to pursue is to formulate concrete suggestions of common research or data comparison in the field of children's motor status. Our Russian colleagues visited us in October 2019, when they visited our premises and laboratories as well as participated at the $10^{\text {th }}$ International Scientific and Professional Conference "Child in Motion" in Portorož, Slovenia. This way we continue our collaboration. 


\title{
POROČILU O OBISKU RUSKE DRŽAVNE UNIVERZE ZA TELESNO VZGOJO, ŠPORT, MLADE IN TURIZEM
}

\author{
Moskva, Ruska federacija, 14.-18. maj 2019
}

V okviru sodelovanja Bileterala Slovenija - Rusija je od 14. do 18. maja 2019 manjša skupina sodelavcev Inštituta za kineziološke raziskave ZRS Koper obiskala Russian State University of Physical Education, Sport, Youth and Tourism, kjer smo bili gostje prof. Sergeja Levuskhinga in dr. Elene Komove. Ogledali smo si univerzo ter laboratorij raziskovalnega inštituta za šport in medicino športa, kjer smo se seznanili z raziskovalnimi sodelavci, opremo, meritvami, raziskavami in delovanjem inštituta. Ruskim partnerjem $\mathrm{v}$ bilateralnem sodelovanju smo ob tem predstavili tudi svoje raziskovalne in znanstvene zmogljivosti.

16. maja 2019 smo sodelovali z uvodnimi predavanji na konferenci XIII. Modern university sport science, namenjeni podiplomskih študentom. Prof. dr. Boštjan Šimunič je sodeloval s predavanjem The use of tensiomiography in athrophy study/Uporaba metode tenziomiografije v študijah atrofij in dr. Saša Pišot s predavanjem Fundamental motor patterns and physical (embodied) capital of a child /Elementarni gibalni vzorci in utelešen gibalni kapital otroka. 17. maja 2019 smo sodelovali na okrogli mizi, ki je potekala v okviru konference Worldwide sport development systems and elite athlete's access to education /Sistemi za razvoj športa in dostop elitnega športnika do izobraževanja. Pogovarjali smo se o trenutnih dobrih praksah in pomanjkljivostih sistemov v Rusiji, Egiptu in Sloveniji. Prof. dr. Rado Pišot je predstavil izsledke projekta Dual career (2D4C), prof. Smolianov pa raziskavo, ki proučuje različne elitne sisteme za razvoj športa po svetu, trenutno v ZDA, Veliki Britaniji, Senegalu in Katarju. V popoldanskem času smo imeli še sestanek s prof. dr. Valentinom Sonkinom, v okviru katerega smo podrobneje spoznali njihovo delo in opredelili precej skupnih interesov pri raziskovanju, predvsem na področju motoričnega razvoja in fiziologije mišice.

Prvi tovrsten obisk je bil uspešen, saj smo dobili pomemben vpogled v delo partnerske institucije ter sklenili nova poznanstva za uspešno prihodnje sodelovanje in raziskovanje na področju komponent gibalnega stanja otrok in mladostnikov s poudarkom na njihovem spremljanju in merjenju. Naslednji korak je namenjen oblikovanju konkretnih predlogov za sodelovanje $\mathrm{v}$ raziskavah in morebitno primerjavo podatkov raziskav na področju gibalnega statusa otrok. Obisk ruskih kolegov je potekal oktobra 2019 , ko so obiskali naše prostore in laboratorije in se udeležili 10. mednarodne znanstvene in strokovne konference Otrok v gibanju v Portorožu.

Saša Pišot 